\title{
Pharmacological Properties of Immuno-Isolated Neuronal Nicotinic Receptors
}

\author{
Paul Whiting and Jon Lindstrom \\ The Salk Institute for Biological Studies, San Diego, California 92138
}

Recently we immunoaffinity-purified an $\mathrm{ACh}$ receptor from chicken brain using a monoclonal antibody raised against receptors from fish electric organ (Whiting and Lindstrom, 1986). This neuronal receptor could be affinity-labeled with ${ }^{3} \mathbf{H}$-bromoacetylcholine, and antisera to it specifically blocked AChinduced depolarization of chicken ciliary ganglion cells. Here we show that this neuronal $\mathrm{ACh}$ receptor binds ${ }^{3} \mathrm{H}$-nicotine with high affinity $\left(K_{\mathrm{D}}=6.61 \pm 0.13 \mathrm{~nm}\right)$. ${ }^{3} \mathrm{H}$-Nicotine binding was blocked by various nicotinic cholinergic ligands but not by $\alpha$-bungarotoxin or the muscarinic antagonist atropine. Binding was also blocked by affinity labeling the receptor with bromoacetylcholine (after reduction by dithiothreitol). Additionally, we were able to use rat antisera raised against the chicken brain receptor to isolate a component from detergent extracts of rat hrain that also bound ${ }^{3} \mathrm{H}$-nicotine with high affinity $\left(K_{\mathrm{D}}=1.5\right.$ nM). The pharmacology of this putative $\mathrm{ACh}$ receptor from rat brain was almost identical to the receptor from chicken brain, and its regional distribution was in good agreement with that of ${ }^{3} \mathrm{H}$-nicotine binding to rodent brain membranes reported by other workers. Thus, by analogy to the receptor we have purified and characterized from chicken brain, this nicotine-binding component from rat brain is probably a functional mammalian neuronal nicotinic ACh'receptor.

Nicotinic acetylcholine receptors (AChRs) from both electric organ and skeletal muscle have been extensively characterized (for reviews, see Popot and Changeux, 1984, or Anholt et al., $1985)$, primarily because of the availability of a probe, $\alpha$-bungarotoxin ( $\alpha \mathrm{BGT}$ ), which binds to these AChRs with both great specificity and high affinity. By contrast, little is known about the neuronal AChR, primarily due to lack of a suitable probe. Although $\alpha$ BGT binds to a component of chicken neuronal tissue that can be affinity-labeled with bromoacetylcholine (BAC) (Kemp et al., 1985; Norman et al., 1982) and that has some amino acid sequence homology with muscle AChRs (ContiTronconi et al., 1985), its physiological significance is uncertain. $\alpha \mathrm{BGT}$ has been shown to block AChR function in neuronal preparations from toads and goldfish (Freeman et al., 1980; Marshall, 1981). However, in chicken and rat neuronal cells, the $\alpha \mathrm{BGT}$ binding component has been shown not to be the electrophysiologically significant AChR (Brown and Fumigalli, 1977; Carbonetto et al., 1978; Jacob and Berg, 1983; Kouvelas

\footnotetext{
Received Jan. 14, 1986; revised Mar. 20, 1986; accepted Mar. 27, 1986.

This work was supported by grants to J.L. from the NIH (NS 11323), the Muscular Dystrophy Association, the Alexander S. Onassis Public Benefit Foundation, and the Los Angeles and California Chapters of the Myasthenia Gravis Foundation. P.W. was supported by a Muscular Dystrophy Association Postdoctoral Fellowship.

We thank Ru-Shya Liu and John Cooper for technical assistance and Dr. Barbara Morley for rat brain dissections and helpful discussions.

Correspondence should be addressed to Jon Lindstrom, The Salk Institute for Biological Studies, P.O. Box 85800, San Diego, CA 92138.

Copyright (C) 1986 Society for Neuroscience $0270-6474 / 86 / 103061-09 \$ 02.00 / 0$
}

et al., 1978; Patrick and Stallcup, 1977a, b; Ravdin and Berg, 1979).

Neuronal AChRs have also been investigated using the radiolabeled cholinergic ligands ${ }^{3} \mathrm{H}$-nicotine (Abood et al., 1980; Clarke et al., 1984; Larsson and Nordberg, 1985; Marks and Collins, 1982; Romano and Goldstein, 1980; Yamada et al., 1985) and ${ }^{3} \mathrm{H}-\mathrm{ACh}$ (Reulecke and Hucho, 1985; Schneider et al., 1985; Schwartz et al., 1982). The binding of these ligands to rodent brain membrane preparations was of high affinity and inhibited poorly, if at all, by $\alpha \mathrm{BGT}$. In autoradiographic studies, Clarke and coworkers $(1985 \mathrm{a}, \mathrm{b})$ were able to demonstrate that ${ }^{3} \mathrm{H}$-nicotine and ${ }^{3} \mathrm{H}-\mathrm{ACh}$ (in the presence of the muscarinic antagonist atropine) bound to rat brain sections with nearly identical patterns. Brain regions rich in binding sites for these ligands were frequently distinct from regions rich in binding sites for ${ }^{125} \mathrm{I}-\alpha \mathrm{BGT}$.

Immunological techniques have also been used to identify neuronal AChRs. Patrick and Stallcup (1977b) showed that although $\alpha \mathrm{BGT}$ could not block AChR function in the rat sympathetic neuronal cell line $\mathrm{PC12}$, antiserum to AChRs from Electrophorus electric organ could block AChR function. A monoclonal antibody (mAb 35) to AChRs from Electrophorus was shown to bind to the lateral spiriform nucleus in chicken brain and its projections to the optic tectum (Lindstrom et al., 1983; Swanson et al., 1983). mAb 35 is directed at the main immunogenic region (MIR), which is located on the extracellular surface of AChR $\alpha$ subunits (Tzartos et al., 1981). Antibodies to the MIR do not inhibit AChR function (Blatt et al., 1986; Lindstrom et al., 1981b). mAb 35 binds to synapses on chicken ciliary ganglion neurons, whereas $\alpha \mathrm{BGT}$ binds to sites outside of the synapse (Jacob et al., 1984). The component in ciliary ganglia identified by $\mathrm{mAb} 35$ has biochemical properties expected of an $A C h R$, and its amount can be modulated by treatment of ganglion cultures with cholinergic ligands (Smith et al., 1985,1986 ). By immunoaffinity chromatography on mAb 35 coupled to Sepharose, we have purified its binding component from chicken brain (Whiting and Lindstrom, 1986). It is an integral membrane glycoprotein, slightly larger than Torpedo AChR monomers, for which 2 subunits have been identified with apparent molecular weights 48,000 and 59,000. The smaller of these subunits binds antibodies that are specific for the $\alpha$ subunit of electric organ and muscle receptors. The component can be affinity-labeled with ${ }^{3} \mathrm{H}-\mathrm{BAC}$ but docs not bind $\alpha \mathrm{BGT}$. Rats immunized with the purified protein developed high antibody titers. Antisera from these rats specifically blocked the ACh-induced depolarization of chicken ciliary ganglion cells in culture (Stollberg et al., 1986). These results clearly suggest that the ncuronal component recognized by mAb 35 is an electrophysiologically active neuronal AChR.

In this study we demonstrate that the chicken neuronal $\mathrm{AChR}$ identified by mAb 35 binds ${ }^{3} \mathrm{H}$-nicotine with high affinity. Furthermore, using antisera raised against purified chicken neuronal $\mathrm{AChR}$, we demonstrate that a homologous protein can be iso- 
lated that is responsible for most or all of the high-affinity ${ }^{3} \mathrm{H}$ nicotine binding in rat brain. The pharmacology of these 2 neuronal AChRs is described.

\section{Materials and Methods}

\section{Antisera and $\boldsymbol{m A b s}$}

$\mathrm{mAb} 35$ was obtained by fusing mouse myeloma cells with spleen cells of rats immunized with purified Electrophorus electric organ AChR (Tzartos et al., 1981). mAb 210 was raised against AChRs purified from fetal bovine muscle and the mouse neuroblastoma cell line $\mathrm{BC} 3 \mathrm{H} 1$ and then partially denatured with SDS (S. Hochschwender and J. Lindstrom, unpublished observations). $\mathrm{mAb} 270$ was derived from rats immunized with immunoaffinity-purified chicken neuronal AChR. Its preparation and characterization, along with that of other $\mathrm{mAbs}$ to neuronal AChRs, will be described in more detail elsewhere. Stocks of mAbs were prepared by ammonium sulfate precipitation of hybridoma culture supernatants. $\mathrm{mAb} 35$ was purified by chromatography on DEAE Affigel Blue (Bio-Rad) (S. Hochschwender and J. Lindstrom, unpublished observations) and was coupled to Sepharose $\mathrm{Cl}-4 \mathrm{~B}$ by cyanogen bromide activation. $\mathrm{mAb} 35$ was also labeled with ${ }^{125}$ I to a specific activity of $2-3 \times 10^{18} \mathrm{cpm} / \mathrm{mol}$ using essentially the same procedure described for $\alpha B G T$ (Lindstrom et al., 1981a, b) and stored at $4^{\circ} \mathrm{C}$ in PBS $(100 \mathrm{~mm}$ $\mathrm{NaCl}, 10 \mathrm{~mm}$ phosphate, $\mathrm{pH} 7.5$ ) containing $10 \mathrm{mg} / \mathrm{ml}$ BSA.

Antisera to the affinity-purified chicken neuronal AChR were prepared as described previously (Whiting and Lindstrom, 1986). For coupling to Sepharose C1-4B, the IgG fraction was prepared by ammonium sulfate precipitation of serum and then coupled at $15 \mathrm{mg} / \mathrm{ml}$ by cyanogen bromide activation.

Goat anti-rat IgG was affinity-purified using a rat IgG-Sepharose column and then coupled to Sepharose $\mathrm{Cl}-4 \mathrm{~B}$ by cyanogen bromide activation.

\section{Preparation of brain detergent extracts}

Chicken and rat brains were obtained from Pel-Freeze Biologicals and stored at $-70^{\circ} \mathrm{C}$. Triton $\mathrm{X}-100$ extracts of brain membranes were prepared as described previously (Whiting and Lindstrom, 1986). Regional dissection of rat brains was carried out by Dr. Barbara Morley, and detergent extracts were similarly prepared. $\mathrm{MAb} 35$ binding sites in chicken brain extracts were determined by a DEAE cellulose assay, as described previously (Whiting and Lindstrom, 1986).

\section{Probing of chicken neuronal AChR immunoblots with $m A b 210$ and $m A b 270$}

Chicken neuronal AChR was immunoaffinity-purified, electrophoretically transferred to diazophenylthioether paper, and subsequently probed with $\mathrm{mAbs}$ as has been previously described (Whiting and Lindstrom, 1986).

\section{${ }^{3} \boldsymbol{H}$-Nicotine binding to immobilized neuronal $A C h R$}

\section{Chicken brain}

Chicken brain detergent extract $(75-100 \mathrm{ml}$ ) was recirculated through $0.25 \mathrm{ml} \mathrm{mAb} 35-S e p h a r o s e$ at $4^{\circ} \mathrm{C}$. After $15 \mathrm{hr}$ the affinity gel was then aliquoted into $1.5 \mathrm{ml}$ plastic microfuge tubes $(0.25-0.6 \mathrm{pmol} \mathrm{mAb} 35$ binding sites per tube, as determined from the depletion of ${ }^{125} \mathrm{I}-\mathrm{mAb}$ 35 binding sites from the detergent extract). The aliquots were washed by resuspending in $1 \mathrm{ml}$ of PBS and $0.5 \%$ Triton X-100 and centrifuging for $20 \mathrm{sec}$ at $10,000 \times \mathrm{g}$ in a microfuge. The required concentration of ${ }^{3} \mathrm{H}$-nicotine (DL- $N$-methyl- ${ }^{3} \mathrm{H}$-nicotine; specific activity $68.8 \mathrm{Ci} / \mathrm{mmol}$; New England Nuclear), stored in aliquots at $-70^{\circ} \mathrm{C}$ in a 100 -fold molar excess of mercaptoacetic acid (Romano and Goldstein, 1980), was then added, in a final volume of $100 \mu 1$ PBS $0.5 \%$ Triton X-100, and incubated for $15 \mathrm{~min}$ at room temperature. The affinity gel was then rapidly washed at $4^{\circ} \mathrm{C}$ with $4 \times 1 \mathrm{ml}$ of cold PBS, $0.5 \%$ Triton $\mathrm{X}-100$, as described above, to remove unbound ${ }^{3} \mathrm{H}$-nicotine. To elute bound protein and ${ }^{3} \mathrm{H}$-nicotine, $100 \mu \mathrm{l}$ of $2.5 \%$ SDS, $5 \% \beta$-mercaptoethanol was then added. After $15 \mathrm{~min}$, duplicate $45 \mu \mathrm{l}$ aliquots were sampled into $5 \mathrm{ml}$ of scintillant $-5 \%$ Biosolve (Beckman), 4\% Liquifluor (New England Nuclear) in toluene-and radioactivity determined by scintillation counting.

The saturability of binding was investigated by varying the concen- tration of ${ }^{3} \mathrm{H}$-nicotine between 0.5 and $20 \mathrm{nM}$. Nonspecific binding was determined in the presence of $1 \mathrm{~mm}$ carbachol. Values for $K_{\mathrm{D}}$ and $B_{\max }$ were derived by Scatchard analysis.

The ability of cholinergic ligands to inhibit ${ }^{3} \mathrm{H}$-nicotine binding to immobilized neuronal $A C h R$ was investigated by including various concentrations of the ligand in the reaction mix. Cytisine, decamethonium, and hexamethonium were obtained from ICN Pharmaceuticals; nicotine was obtained from Eastman Kodak; mecamylamine was obtained from Merck Sharpe and Dohme; atropine, curare, $\mathrm{ACh}$, and carbachol were obtained from Sigma. The $\mathrm{IC}_{50}$ was determined as the concentration of ligand that inhibited $50 \%$ of the specific ${ }^{3} \mathrm{H}$-nicotine binding. The $K_{\mathrm{I}}$ was calculated from $K_{\mathrm{I}}=\mathrm{IC}_{\mathrm{s} 0} /\left(1+\left[{ }^{3} \mathrm{H}\right.\right.$-nicotine $\left.] / K_{\mathrm{D}}\right)$.

The inhibition of ${ }^{3} \mathrm{H}$-nicotine binding by the affinity label BAC was also investigated. Aliquots of immobilized receptor were reduced with $100 \mu 10.1-1 \mathrm{~mm}$ dithiothreitol (DTT) in PBS, $0.5 \%$ Triton X-100 for $40 \mathrm{~min}$ at room temperature. The aliquots were then washed with $1 \mathrm{ml}$ PBS, $0.5 \%$ Triton X-100 and alkylated for $5 \mathrm{~min}$ with $0.001-1.0 \mu \mathrm{M}$ BAC (prepared by Dr. K. Wan using the method of Chiou and Sastry, 1968) in the same buffer. The affinity gel was then washed with $3 \times 1$ $\mathrm{ml}$ PBS, $0.5 \%$ Triton X-100 and then incubated for 10 min with 100 $\mu l$ of $0.1 \mathrm{~mm}$ dithiobis (2-nitrobenzoic acid) (DTNB) in the same buffer. After washing twice more, ${ }^{3} \mathrm{H}$-nicotine binding was determined as described above. To determine the total ${ }^{3} \mathrm{H}$-nicotine binding, parallel incubations were carried out omitting the BAC labeling step.

\section{Rat brain}

Rat brain extract $(200-800 \mu 1)$ was gently shaken in $1.5 \mathrm{ml}$ microfuge tubes for 4-6 hr at room temperature and then $15 \mathrm{hr}$ at $4^{\circ} \mathrm{C}$ with $15 \mu \mathrm{l}$ of anti-chicken neuronal AChR serum and $25 \mu \mathrm{l}$ goat anti-rat IgGSepharose, or 5-50 $\mu \mathrm{l}$ of directly coupled anti-chicken neuronal AChRSepharose. I abeling with ${ }^{3} \mathrm{H}$-nicotine was then carried out as has been described above for chicken neuronal AChR.

\section{Binding of ${ }^{3} \mathrm{H}$-nicotine in brain detergent extract}

Brain detergent extract was first dialyzed against PBS, $0.5 \%$ Triton $\mathrm{X}-100$, and aliquots $(100 \mu \mathrm{l})$ were incubated for $15 \mathrm{~min}$ at room temperature with $20 \mathrm{~nm}{ }^{3} \mathrm{H}$-nicotine and then applied to a $1 \times 6 \mathrm{~cm}$ Sephadex G25 column equilibrated with PBS $0.5 \%$ Triton X-100 at $4^{\circ} \mathrm{C}$. Following elution with the same buffer, $100 \mu \mathrm{l}$ fractions were collected and radioactivity determined by scintillation counting as described above. The separation procedure took approximately $3 \mathrm{~min}$. The total radioactivity in the first peak was summated to determine bound ${ }^{3} \mathrm{H}$-nicotine. The specificity of the binding was demonstrated by inclusion of $1 \mathrm{~mm}$ carbachol in the reaction mixture.

\section{Toxin binding}

$\alpha$ BGT was radioiodinated as previously described (Lindstrom et al., 1981a) to specific activities of $3-4 \times 10^{17} \mathrm{cpm} / \mathrm{mol}$. Toxin binding to solubilized rat and chicken brain was measured by a DEAE ion-exchange assay and was performed as previously described (Whiting and Lindstrom, 1986).

\section{Results}

\section{${ }^{3} H$-Nicotine binding to immobilized chicken neuronal $A C h R$} Chicken neuronal AChR was immobilized upon $\mathrm{mAb} 35-\mathrm{Seph}$ arose. This approach was taken both to purify and to concentrate the $\mathrm{AChR}$ from the detergent extract in a single step. We have previously used this technique to affinity-label the neuronal AChR with ${ }^{3} \mathrm{H}-\mathrm{BAC}$ (Whiting and Lindstrom, 1986). Immobilization on $\mathrm{mAb} 35$ should not affect ligand binding since $\mathrm{mAbs}$ to the MIR bind to AChRs without altering their function (Blatt et al., 1986; Lindstrom et al., 1983). ${ }^{3} \mathrm{H}-\mathrm{Nicotine}$ was allowed to bind to the $\mathrm{AChR}$ for $15 \mathrm{~min}$ at room temperature, an incubation time that gave maximal binding (data not shown). Washing of the labeled AChR was done rapidly at $4^{\circ} \mathrm{C}$ to minimize dissociation of bound ligand. Figure $1 A$ demonstrates saturable binding of ${ }^{3} \mathrm{H}$-nicotinc to immobilized chicken neuronal AChR. Negligible binding was observed in the presence of $1 \mathrm{~mm}$ carbachol. Similarly, no binding of ${ }^{3} \mathrm{H}$-nicotine was observed to antibody-Sepharose which did not have immobi- 

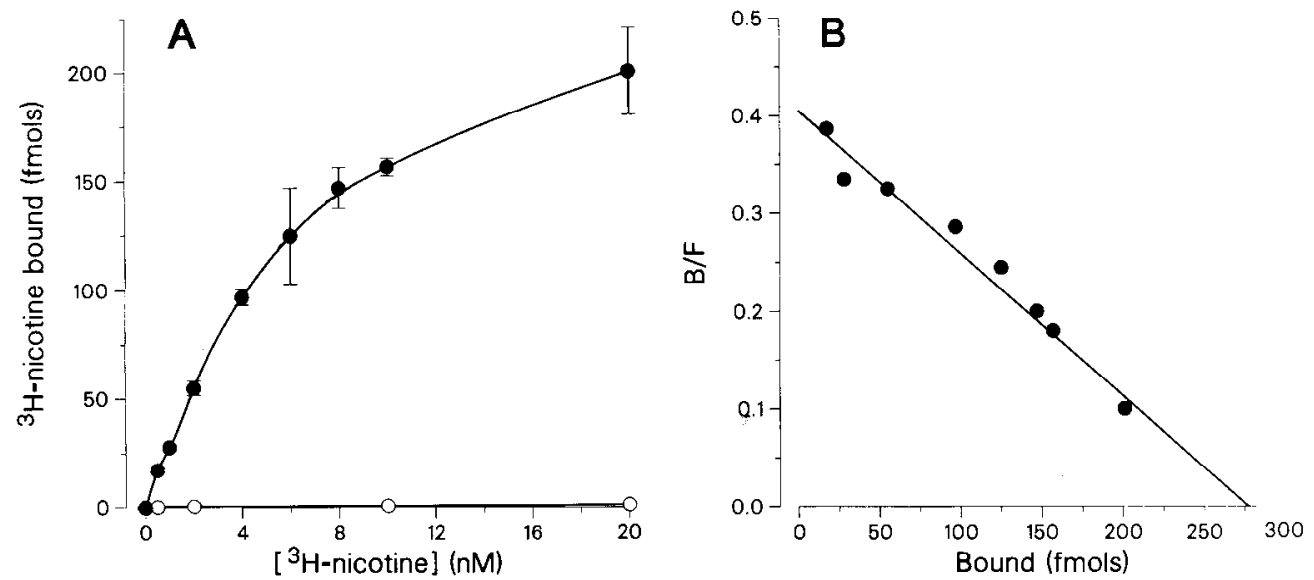

Figure 1. Binding of ${ }^{3} \mathrm{H}$-nicotine to immobilized chick neuronal $\mathrm{AChR}, A$, Chick brain detergent extract ( $\left.85 \mathrm{ml}\right)$ was recirculated for $15 \mathrm{hr}, 4^{\circ} \mathrm{C}$, through $250 \mu \mathrm{l}$ of mAb 35-Sepharose. Affinity gel was divided into 40 aliquots of 0.54 pmol ${ }^{125} \mathrm{I}-\mathrm{mAb} 35$ binding sites per aliquot, washed with $2 \mathrm{ml}$ PBS, $0.5 \%$ Triton X-100 and incubated for $15 \mathrm{~min}$, room temperature, in $100 \mu \mathrm{l}$ of the same buffer containing various concentrations of ${ }^{3} \mathrm{H}$-nicotine in the presence or absence of $1 \mathrm{~mm}$ carbachol. Aliquots were rapidly washed with $4 \times 1 \mathrm{ml}$ ice-cold PBS, $0.5 \%$ Triton X-100. Then $100 \mu \mathrm{l}$ of $5 \%$ SDS, $2.5 \% \beta$-mercaptoethanol was then added, and after $15 \mathrm{~min}, 45 \mu \mathrm{l}$ duplicates sampled for scintillation counting and the ${ }^{3} \mathrm{H}$ nicotine binding per aliquot determined. Each point is the mean \pm SD of the values from 3 aliquots. Symbols: $\mathbf{0}$, binding in the absence of carbachol; $O$, binding in the presence of carbachol. $B$, Scatchard plot of data from $A$.

lized neuronal AChR (not shown). Scatchard analysis (Fig. 1B) indicated binding with a single affinity, $K_{\mathrm{D}}=6.61 \pm 0.13 \mathrm{nM}$ (mean $\pm \mathrm{SD}, 3$ experiments). The total nicotine binding to the immobilized AChR, $B_{\max }$, amounted to about half of the amount of $\mathrm{mAb} 35$ binding sites immobilized $(0.53 \pm 0.02: 1 \pm 0.12$; ratio of ${ }^{3} \mathrm{H}$-nicotine binding sites to ${ }^{125} \mathrm{I}-\mathrm{mAb} 35$ binding sites, mean $\pm \mathrm{SD}, 3$ experiments). This indicates that the specific activity of the immobilized AChR for nicotine binding is very high.

\section{${ }^{3} \mathrm{H}$-Nicotine binding to immobilized rat brain $A C h R$}

$\mathrm{mAb} 35$ and $\mathrm{mAb} 210$ were also able to immobilize some nicotine binding sites from rat brain extracts, but rat antisera raised against the chicken neuronal AChR were far more effective. Figure 2 shows that the $\operatorname{IgC}$ fraction of rat anti-chicken neuronal AChR serum, directly coupled to Sepharose, binds the neuronal AChR from rat brain in a concentration-dependent manner. Similar results were obtained when the neuronal AChR was immobilized indirectly with anti-chicken neuronal AChR serum-goat anti-rat IgG-Sepharose. As was found for the chicken brain AChR, ${ }^{3} \mathrm{H}$-nicotine bound in a saturable manner to immobilized rat neuronal AChR with a single affinity, $K_{\mathrm{D}}=1.5$ nM (data not shown).

\section{${ }^{3} H$-Nicotine binding to chicken and rat neuronal $A C h R$ in detergent extract}

The binding of ${ }^{3} \mathrm{H}$-nicotine to AChR in detergent extracts of brain was investigated to determine whether the neuronal AChR bound by anti-receptor antibodies was the only nicotine binding component, or whether it represented only a small fraction of the total nicotine binding sites. The total number of ${ }^{3} \mathrm{H}$-nicotine binding sites in both chicken and rat brain extracts was determined before and after incubation with $\mathrm{mAb} 270$ bound to goat anti-rat $\mathrm{IgG}-$ Sepharose. This $\mathrm{mAb}$ was raised from rats immunized with chicken neuronal $A C h R$ and binds neither to chicken skeletal muscle AChR nor to the chicken or rat brain $\alpha \mathrm{BGT}$ binding proteins. Its production and characterization will be described in detail elsewhere. Here we demonstrate that this mAb specifically binds to the 48,000 apparent molecular weight subunit of immunoblotted chicken neuronal AChR (Fig. 3, lane 1). As we have previously reported (Whiting and Lindstrom,
1986), this subunit is also bound by $\mathrm{mAb} 210$, which is specific for the $\alpha$ subunit of skeletal muscle AChR (Fig. 3, lane 2), and by antiserum to Torpedo AChR $\alpha$ subunits (not shown), and it is therefore considered to be the $\alpha$ subunit analog.

To measure the nicotine binding in crude detergent extract, it was necessary to dialyze the extracts against PBS, $0.5 \%$ Triton $\mathrm{X}-100$; we observed little binding of ${ }^{3} \mathrm{H}$-nicotine to nondialyzed brain extract. Extracts were prepared in a buffer containing $2 \%$ Triton X-100, $50 \mathrm{~mm}$ Tris, pH 8.8, 1 mm EDTA, 1 mM EGTA, $5 \mathrm{~mm}$ iodoacetamide, $5 \mathrm{~mm}$ benzamidine, and $2 \mathrm{~mm}$ phenyl-

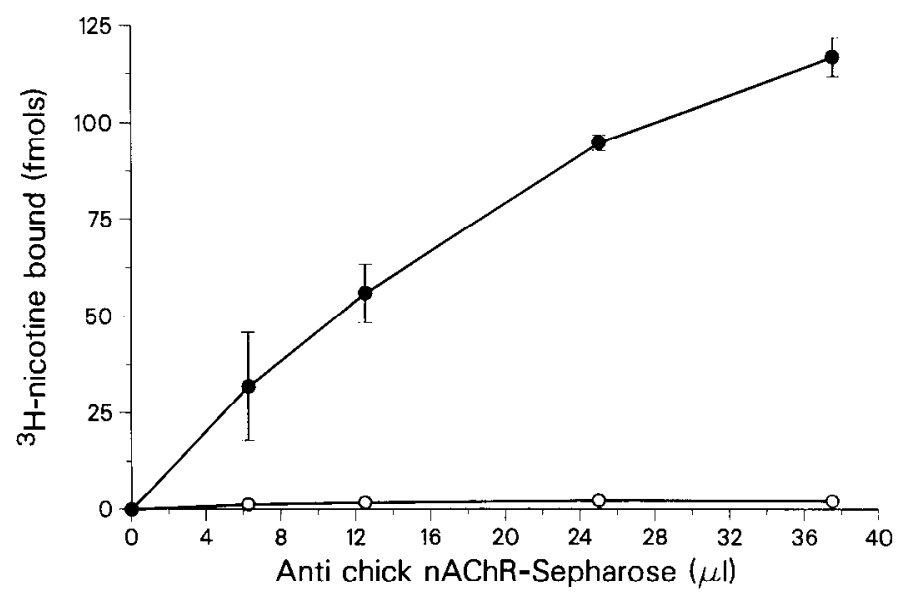

Figure 2. Binding of anti-chick neuronal AChR-Sepharose to the ${ }^{3} \mathrm{H}-$ nicotine binding site from rat brain. Triplicate aliquots of anti-chick neuronal AChR-Sepharose were gently shaken overnight at $4^{\circ} \mathrm{C}$ with $400 \mu \mathrm{l}$ of rat brain detergent extract. After washing with $2 \times 1 \mathrm{ml}$ of PBS, $0.5 \%$ Triton X-100, the aliquots were incubated in $100 \mu \mathrm{l}$ of 20 nM ${ }^{3} \mathrm{H}$-nicotine in the same buffer with or without $1 \mathrm{~mm}$ carbachol for $15 \mathrm{~min}$ at room temperature. Aliquots were then washed at $4^{\circ} \mathrm{C}$ with $4 \times 1 \mathrm{ml} \mathrm{PBS}, 0.5 \%$ Triton X-100 and $100 \mu \mathrm{l}$ of $5 \%$ SDS, $2.5 \% \beta$-mercaptoethanol was then added; after $15 \mathrm{~min}, 2 \times 45 \mu \mathrm{l}$ samples were taken for scintillation counting. The ${ }^{3} \mathrm{H}$-nicotine bound per aliquot was then determined. Symbols: $\boldsymbol{\theta}$, binding in the absence of carbachol; $\mathrm{O}$, binding in the presence of carbachol. From these data, the concentration of ${ }^{3} \mathrm{H}$-nicotine binding sites in the rat brain detergent extract was 0.30 $\mathrm{nM}$, or $0.75 \mathrm{pmol} / \mathrm{g}$ brain. 


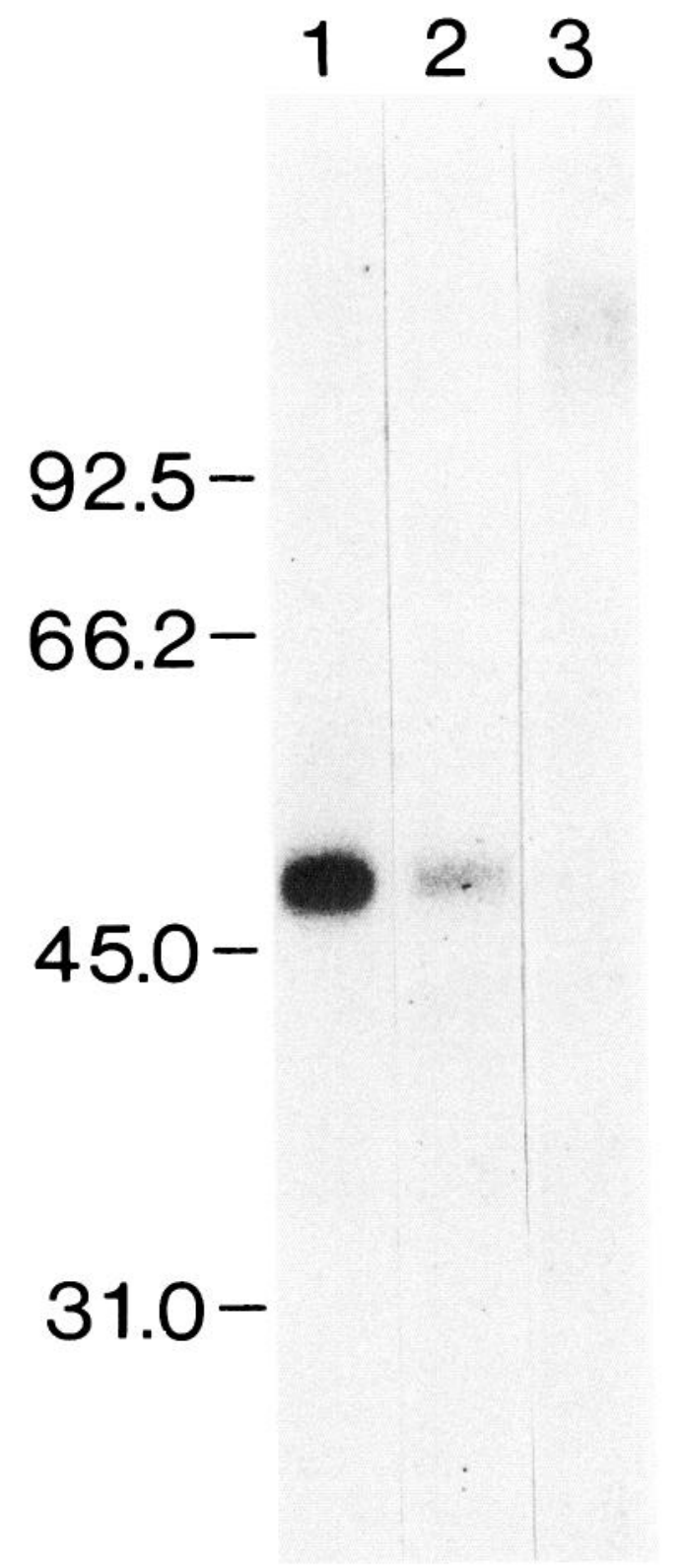

Figure 3. Binding of $\mathrm{mAb} 210$ and $\mathrm{mAb} 270$ to immunoblots of chick neuronal AChR. Affinity-purified chick neuronal AChR (30 pmol ${ }^{125} \mathrm{I}-$ mAb 35 binding sites) was resolved by SDS-PAGE and electrophoretically transferred to activated DPT paper. The paper was cut into 20 strips containing approximately $0.6 \mathrm{pmol}$ neuronal AChR per strip. These strips were then probed with $10 \mathrm{~nm}$ mAb 210, undiluted $\mathrm{mAb}$ 270 culture supernatant, or control culture supernatant, using previously described techniques (Whiting and Lindstrom, 1986). mAb binding was visualized by incubation with $0.5 \mathrm{~nm}{ }^{125} \mathrm{I}$-goat anti-rat $\mathrm{IgG}$ and subsequent autoradiography for $15 \mathrm{hr}$ at $-70^{\circ} \mathrm{C}$ using preflashed Kodak XAR-5 film and an intensifying screen. Apparent molecular weights were determined by resolving molecular-weight standards (Bio-Rad) on the same gel and staining for protein with Coomassie Blue. Lane 1, mAb 210; lane 2, mAb 270; lane 3, control culture supernatant.

methylsulfonyl fluoride. We did not determine what components of the extract or buffer inhibited binding prior to dialysis.

After labeling of detergent extracts, the bound ${ }^{3} \mathrm{H}$-nicotine was separated from the free by gel filtration, which was done rapidly at $4^{\circ} \mathrm{C}$ to minimize ligand dissociation. Total binding was then determined by summation of radioactivity in the first peak. Specificity of ${ }^{3} \mathrm{H}$-nicotine binding measured in this way

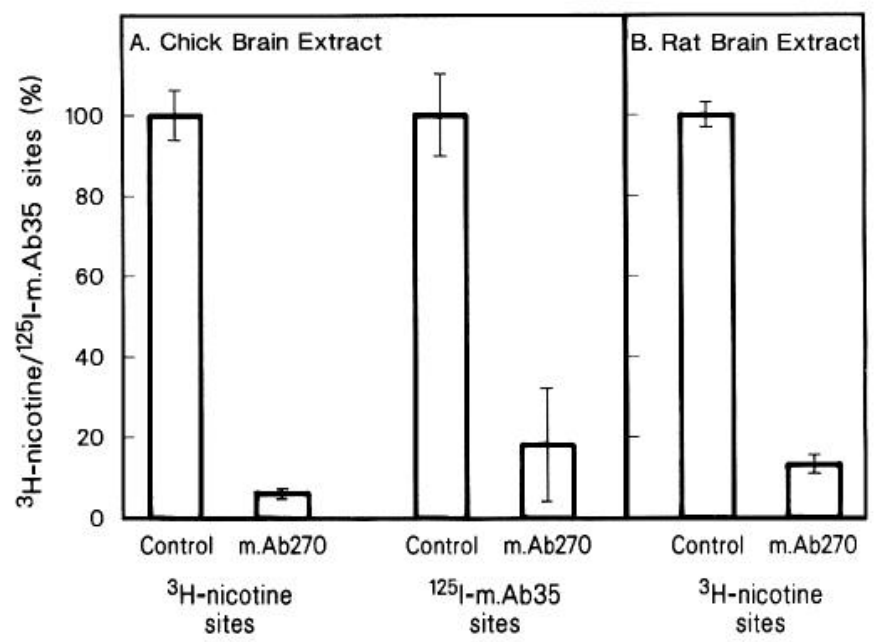

Figure 4. Depletion of ${ }^{3} \mathrm{H}$-nicotine binding sites from chick and rat brain detergent extract by mAb 270 . $A$, Chick brain detergent extract $(600 \mu \mathrm{l})$ was gently shaken overnight at $4^{\circ} \mathrm{C}, 50 \mu \mathrm{l}$ of $\mathrm{mAb} 270$ (concentrated approximately 20 -fold from culture supernatant by ammonium sulfate precipitation) and $50 \mu \mathrm{l}$ of goat anti-rat IgG-Sepharose. Triplicate $100 \mu \mathrm{l}$ aliquots of the supernatants were then incubated for $15 \mathrm{~min}$ at room temperature with $20 \mathrm{nM}^{3} \mathrm{H}$-nicotine, and bound nicotine was then determined by gel filtration, as is described in Materials and Methods. ${ }^{3} \mathrm{H}$-Nicotine binding was also determined for the nondepleted chick brain extract. Results are expressed considering the ${ }^{3} \mathrm{H}$-nicotine binding sites in the nondepleted extract as $100 \%$ and are the mean \pm $\mathrm{SD}$ of 3 determinations. ${ }^{125} \mathrm{I}-\mathrm{mAb} 35$ binding sites in the original extract and the depleted extract were determined by DEAE assay (Whiting and Lindstrom, 1986). Results are expressed considering the ${ }^{125} \mathrm{I}-\mathrm{mAb} 35$ binding sites in the nondepleted extract as $100 \%$ and are the mean \pm SD of quadruplicate determinations. Chicken brain extract had a concentration of $0.21 \mathrm{nM}^{3} \mathrm{H}$-nicotine binding sites $(0.26 \mathrm{pmol} / \mathrm{g}$ brain $)$ and $0.36 \mathrm{~nm}{ }^{125} \mathrm{I}-\mathrm{mAb} 35$ binding sites $(0.45 \mathrm{pmol} / \mathrm{g}$ brain $) . B$, Rat brain extract $(400 \mu \mathrm{l})$ was gently shaken overnight, $4^{\circ} \mathrm{C}$ with $40 \mu \mathrm{l}$ of mAb 270 and $40 \mu \mathrm{l}$ of goat anti-rat IgG-Sepharose. Triplicate $100 \mu \mathrm{l}$ aliquots of the supernatants were then incubated for $15 \mathrm{~min}$, room temperature, with $20 \mathrm{~nm}{ }^{3} \mathrm{H}$-nicotine, and bound nicotine was then determined by gel filtration (see Materials and Methods). ${ }^{3} \mathrm{H}-\mathrm{Nicotine}$ binding to nondepleted rat brain extract was also determined. Results are expressed considering the ${ }^{3} \mathrm{H}$-nicotine binding sites in the nondepleted extract as $100 \%$ and are the mean \pm SD of triplicate determinations. The rat brain extract had a concentration of $0.45 \mathrm{~nm}{ }^{3} \mathrm{H}$-nicotine binding sites $(0.93$ $\mathrm{pmol} / \mathrm{g}$ brain).

was demonstrated by the observation that when $1 \mathrm{~mm}$ carbachol was included in the reaction volume, binding was completely inhibited.

Figure $4 A$ demonstrates that $\mathrm{mAb} 270$ is able to deplete the majority of both the nicotine binding sites and the mAb 35 binding sites from chicken brain extract, indicating that the neuronal $\mathrm{AChR}$ bound by $\mathrm{mAb} 35$ is a major high-affinity nicotine binding site in chicken brain. Figure $4 B$ also demonstrates that $\mathrm{mAb} 270$ is able to deplete the majority of the nicotine binding sites from rat brain extract. Ninety-two percent of the nicotine binding sites depleted from the rat brain extract were immobilized upon the mAb 270-goat anti-rat IgG-Sepharose (as determined by incubation with ${ }^{3} \mathrm{H}$-nicotine), confirming that the depletion of nicotine binding sites was due to their immobilization by the antibody. The ${ }^{125} \mathrm{I}-\mathrm{mAb} 35$ binding sites could not be measured accurately in rat brain extract because $\mathrm{mAb}$ 35 exhibits very low cross-reactivity with the rat brain nicotine binding component.

\section{Inhibition of ${ }^{3} \mathrm{H}$-nicotine binding by cholinergic ligands}

The effect of nicotinic and muscarinic ligands on the binding of ${ }^{3} \mathrm{H}$-nicotine to immobilized chicken and rat neuronal AChRs 
Chick Brain Cytisine $>$ Nicotine $>$ Carbachol $>$ Curare

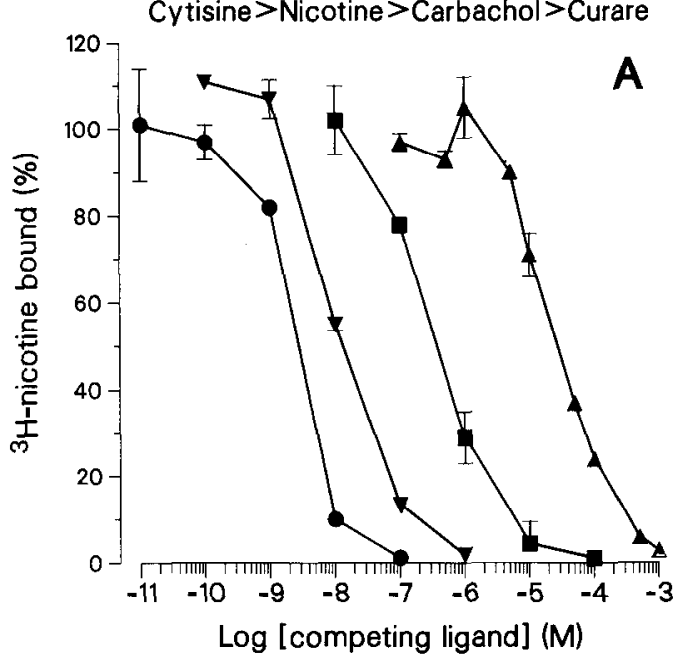

Rat Brain

Cytisine $>$ Carbachol $>$ Curare

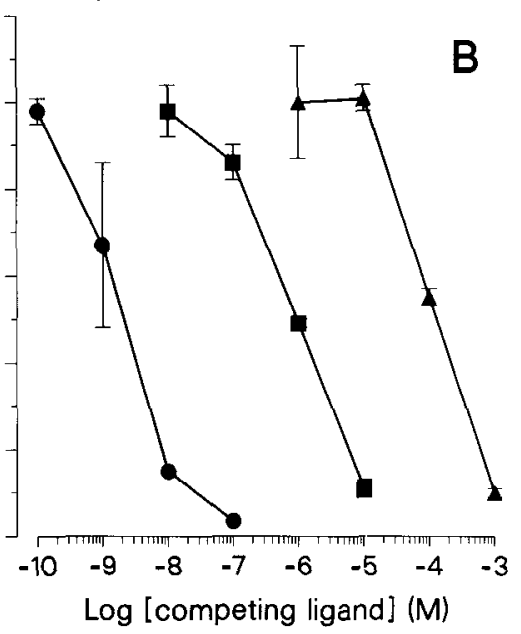

Figure 5. Inhibition of ${ }^{3} \mathrm{H}$-nicotine binding to immobilized chicken neuronal AChR and rat neuronal AChR by cholinergic ligands. $A$, Chicken neuronal AChR was immobilized upon $\mathrm{mAb}$ 35-Sepharose, as described in Materials and Methods, and divided into aliquots containing between 0.5 and $0.6 \mathrm{pmol} \mathrm{mAb} 35$ binding sites. Aliquots were incubated for $15 \mathrm{~min}$ at room temperature with $100 \mu 1$ of $10 \mathrm{nM}$ of ${ }^{3} \mathrm{H}$-nicotine in the presence or absence of various concentrations of cholinergic ligands. After washing with $4 \times 1 \mathrm{ml}$ of ice-cold PBS, $0.5 \%$ Triton X-100, the ${ }^{3} \mathrm{H}$ nicotine bound was determined as described in Materials and Methods. Each point is the mean \pm SD of triplicate determinations, and the results are expressed considering ${ }^{3} \mathrm{H}$-nicotine binding in the absence of competing ligands as $100 \%$. $B$. Aliquots ( $\left.800 \mu \mathrm{l}\right)$ of rat brain detergent extract were incubated for $4 \mathrm{hr}$ at room temperature and then overnight at $4^{\circ} \mathrm{C}$ with $15 \mu \mathrm{l}$ of anti-chick neuronal AChR serum and $25 \mu \mathrm{l}$ of goat anti-rat IgGSepharose, and then washed with $2 \times 1 \mathrm{ml}$ of PBS, $0.5 \%$ Triton X-100. Aliquots were then incubated for 15 min at room temperature with 100 $\mu \mathrm{l}$ of $10 \mathrm{nM}{ }^{3} \mathrm{H}$-nicotine in the presence or absence of cholinergic ligands, washed with $4 \times 1 \mathrm{ml}$ of ice-cold PBS, $0.5 \%$ Triton X-100, and bound ${ }^{3} \mathrm{H}$-nicotine determined as in Materials and Methods. Each point is the mean \pm SD of triplicate determinations, and the results are expressed considering ${ }^{3} \mathrm{H}$-nicotine binding in the absence of competing ligands as $100 \%$. Symbols: $\boldsymbol{\bullet}$, cytisine; $\boldsymbol{\nabla}$, nicotine; $\boldsymbol{\square}$, carbachol; $\boldsymbol{\wedge}$, curare.

was determined to further define their pharmacology. The binding curves for some of these ligands are shown in Figure 5. The $\mathrm{IC}_{50}$ and $K_{\mathrm{I}}$ values for all the ligands tested are shown in Table 1. Chicken and rat neuronal AChRs had very similar ligand binding properties, as would be expected for homologous molecules. Both had high affinities for cholinergic agonists and comparatively low affinities for antagonists. $\alpha \mathrm{BGT}$, at concentrations of up to $1 \mu \mathrm{M}$, did not exhibit any inhibition of ${ }^{3} \mathrm{H}$-nicotine binding. Similarly, the $\mathrm{IC}_{50}$ for the muscarinic antagonist atropine was greater than $1 \mathrm{~mm}$, confirming the nicotinic pharmacology of this neuronal AChR.

\section{Affinity labeling of the neuronal $A C h R$}

$\mathrm{BAC}$ is an affinity-labeling reagent that reacts with the $\mathrm{AChR}$ only after reduction of a disulfide bond adjacent to the neurotransmitter binding site (Damle et al., 1978). It has been found that $\mathrm{BAC}$ is more reactive with 1 of the 2 acetylcholine binding sites of electric organ and muscle AChR (Wolosin et al., 1980). On chicken ciliary ganglion cells BAC irreversibly inhibits aclivation of the AChR only after reduction with DTT (Stollberg et al., 1984). We have previously shown that the neuronal AChR from chicken brain can be affinity labeled with ${ }^{3} \mathrm{H}-\mathrm{BAC}$ (Whiting and Lindstrom, 1986). In the present study we have further investigated the nature of the BAC labeling. Figure $6 \mathrm{~A}$ shows the effect of DTT concentration on the affinity labeling of immobilized chicken neuronal AChR. The curve for inhibition of ${ }^{3} \mathrm{H}$-nicotine binding was clearly not biphasic. Similarly, when the DTT concentration was constant $(1 \mathrm{~mm})$ and the BAC concentration varied, the inhibition curve indicated affinity labeling at a single site, or more than one site of equal reactivity (Fig. $6 B)$.

We also investigated whether the rat neuronal $\mathrm{AChR}$ could

Table 1. Inhibition of ${ }^{3} \mathrm{H}$-nicotine binding by cholinergic ligands

\begin{tabular}{|c|c|c|c|c|}
\hline \multirow[b]{2}{*}{ Ligand } & \multicolumn{2}{|c|}{ Chicken neuronal AChR } & \multicolumn{2}{|c|}{ Rat neuronal AChR } \\
\hline & $\mathrm{IC}_{50}(\mathrm{M})$ & $K_{1}(\mathrm{M})$ & $\mathrm{IC}_{50}(\mathrm{M})$ & $K_{1}(\mathrm{M})$ \\
\hline Cytisine & $2.8 \times 10^{-9}$ & $1.1 \times 10^{-9}$ & $2.1 \times 10^{-9}$ & $2.7 \times 10^{-10}$ \\
\hline Nicotine & $1.3 \times 10^{-8}$ & $5.2 \times 10^{-9}$ & $--^{a}$ & - \\
\hline Acetylcholine & $1.4 \times 10^{-8}$ & $5.6 \times 10^{-9}$ & $-a$ & - \\
\hline Carbachol & $3.7 \times 10^{-7}$ & $8.4 \times 10^{-8}$ & $9.5 \times 10^{-7}$ & $1.2 \times 10^{-7}$ \\
\hline Curare & $2.8 \times 10^{-5}$ & $1.1 \times 10^{-5}$ & $1.3 \times 10^{-4}$ & $1.7 \times 10^{-5}$ \\
\hline Decamethonium & $2.2 \times 10^{-5}$ & $8.7 \times 10^{-6}$ & $--^{a}$ & - \\
\hline Hexamethonium & $>1 \times 10^{-3}$ & - & $-{ }^{a}$ & - \\
\hline Mecamylamine & $>1 \times 10^{-3}$ & - & $-{ }^{a}$ & - \\
\hline$\alpha \mathrm{BGT}$ & $>1 \times 10^{-6}$ & - & $>1 \times 10^{-6}$ & - \\
\hline Atropine & $>1 \times 10^{-3}$ & - & $>1 \times 10^{-3}$ & - \\
\hline
\end{tabular}

${ }^{a}$ Not determined. 

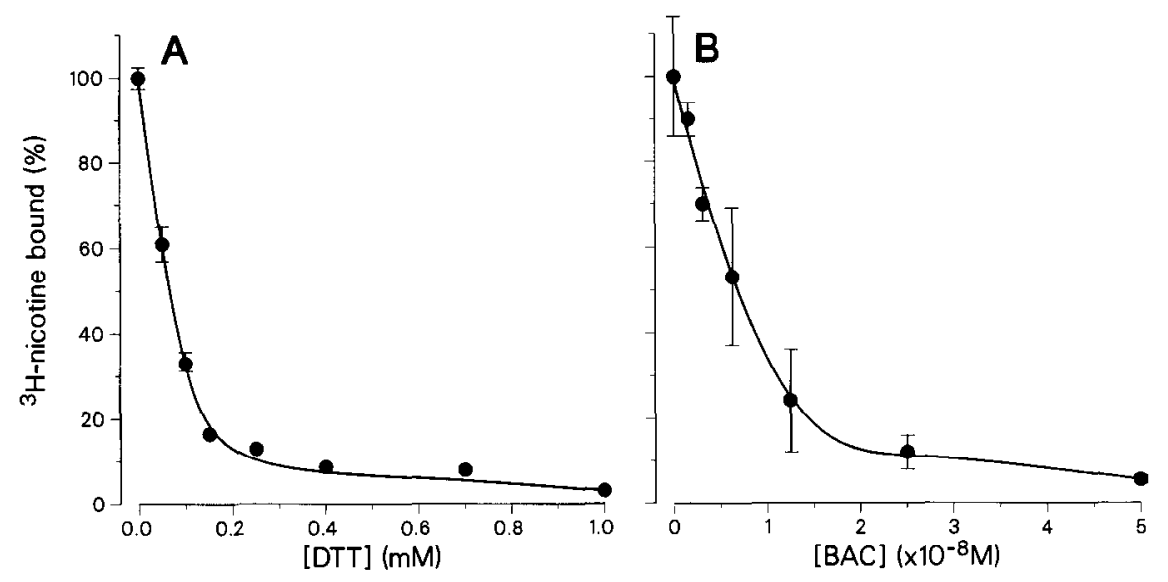

Figure 6. Affinity labeling of chicken neuronal AChR with BAC. $A$, Titration of DTT concentration. Chicken brain detergent extract (80 ml) was recirculated through $250 \mu \mathrm{l}$ of $\mathrm{mAb} 35-$ Sepharose for $15 \mathrm{hr}$ at $4^{\circ} \mathrm{C}$, and the affinity gel then divided into 36 aliquots, containing 0.44 pmol ${ }^{125}$ $\mathrm{mAb} 35$ binding sites per aliquot. The aliquots were washed with $2 \times 1 \mathrm{ml}$ of PBS, $0.5 \%$ Triton and then reduced for $40 \mathrm{~min}$ at room temperature, with $150 \mu \mathrm{l}$ of various concentrations of DTT in the same buffer. After washing with $1 \mathrm{ml}$ PBS, $0.5 \%$ Triton (without DTT), the aliquots were resuspended in $70 \mu \mathrm{l}$ of the same buffer containing $10 \mu \mathrm{M}$ BAC, incubated for $5 \mathrm{~min}$ at room temperature, and then washed with $3 \times 1 \mathrm{ml} \mathrm{PBS}$, $0.5 \%$ Triton X-100 to remove noncovalently bound BAC. Samples were then incubated for 10 min with $0.1 \mathrm{~mm}$ DTNB, in the same buffer, washed again with $2 \times 1 \mathrm{ml} \mathrm{PBS}, 0.5 \%$ Triton X-100, and then incubatcd with $100 \mu 110 \mathrm{nM}{ }^{3} \mathrm{H}$-nicotine for 15 min at room temperature. Bound ${ }^{3} \mathrm{H}$ nicotine was then determined as in Materials and Methods. A parallel incubation was carried out with the BAC labeling step omitted, the ${ }^{3} \mathrm{H}$ nicotine binding subsequently determined was considered as $100 \%$, and the binding to the BAC-labeled aliquots expressed relative to this. Nonspecific binding of ${ }^{3} \mathrm{H}$-nicotine was determined in the presence of $1 \mathrm{~mm}$ carbachol and represented less than $2 \%$ of the total binding. Each point represents the mean \pm SD of triplicate determinations. $B$, Titration of BAC concentration. Chick brain detergent extract ( $80 \mathrm{ml})$ was recirculated for $15 \mathrm{hr}$, $4^{\circ} \mathrm{C}$, through $250 \mu \mathrm{l}$ of $\mathrm{mAb} 35-$ Sepharose and the affinity gel divided into 36 aliquots, 0.33 pmol ${ }^{125} \mathrm{I}$-mAb 35 binding sites per aliquot. The aliquots were then reduced with $1 \mathrm{mM}$ DTT, affinity-labeled with various concentrations of BAC, reoxidized with $0.1 \mathrm{mM}$ DTNB, and then ${ }^{3} \mathrm{H}$ -

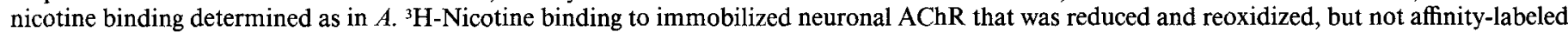
with BAC, was considered as $100 \%$ and ${ }^{3} \mathrm{H}$-nicotine binding to BAC-labeled aliquots expressed as a percentage. Each point represents the mean \pm $\mathrm{SD}$ of triplicate determinations.

be affinity-labeled with BAC. After reduction with 1 mM DTT, affinity labeling with $10 \mu \mathrm{M} B A C$, and reoxidation with $0.1 \mathrm{~mm}$ DTNB, the ${ }^{3} \mathrm{H}$-nicotine binding to rat neuronal AChR immobilized upon anti-chicken neuronal AChR-goat anti-rat IgGSepharose was reduced to $15 \pm 2 \%$ (mean $\pm \mathrm{SD}, 3$ determinations) of that obtained when $\mathrm{AChR}$ was reduced and reoxidized, but not affinity-labelcd. Hence, rat ncuronal AChR also has a disulfide bridge adjacent to its neurotransmitter binding site(s).

\section{Inhibition of ${ }^{3} \mathrm{H}$-nicotine binding by anti-chicken neuronal AChR serum}

It was of interest to determine whether the anti-chicken neuronal AChR serum used in these studies had antibodies directed to the neurotransmitter binding site. Immobilized chicken neuronal $A C h R$ was preincubated with various dilutions of serum, and ${ }^{3} \mathrm{H}$-nicotine binding then determined. The antiserum significantly inhibited ${ }^{3} \mathrm{H}$-nicotine binding (Fig. 7), indicating a population of antibodies in the serum directed against the neurotransmitter binding site.

Using a solid-phase immunoassay, we previously determined that the titer of the antiserum used in Figure 6 against chicken neuronal AChR was $66 \mu \mathrm{M}$ (Whiting and Lindstrom, 1986). From Figure 7 it can be calculated that the titer of the antineurotransmitter binding site antibodies in this serum was $22 \mathrm{nmol}$ ${ }^{3} \mathrm{H}$-nicotine binding inhibited/liter serum. Because the antineurotransmitter binding site antibodies are such a small proportion $(<0.1 \%)$ of the total antineuronal AChR activity, they have a negligible effect upon total ${ }^{3} \mathrm{H}$-nicotine binding determined using antiserum to immobilize the neuronal AChR. Also, the low concentration of antisite antibodies makes it unlikely that they are responsible for the inhibition of AChR function (meaning the depolarization of chick ciliary ganglion neurons by $3 \mathrm{~mm}$ carbachol) observed using 1/100 dilutions of this serum (Stoll- berg et al., 1986). Other antibody specificities, such as those directcd against the ion channcl, may account for the observed inhibition of function.

\section{Regional distribution of neuronal $A C h R$ in rat brain}

Rat brains were dissected into 6 different regions and detergent extracts prepared. The neuronal AChRs from each extract were then immobilized on anti-chicken neuronal AChR-Sepharose and ${ }^{3} \mathrm{H}$-nicotine binding determined (Fig. $8 \mathrm{~A}$ ). Simultaneously, the ${ }^{125}$ I $-\alpha$ BGT binding was determined by DEAE assay (Fig. $8 B$ ). For whole brain, we determined a value of $0.70 \pm 0.07$ pmol ${ }^{3} \mathrm{H}$-nicotine binding sites/g rat brain (mean $\pm \mathrm{SD}, 3$ preparations). The concentration of neuronal AChR in the brain regions, determined by ${ }^{3} \mathrm{H}$-nicotine binding, ranged from 0.23 to $1.05 \mathrm{pmol} / \mathrm{g}$ rat brain. It was highest in the superior colliculus, thalamus, and interpeduncular nucleus, and lowest in the cerebellum. ${ }^{125}$ I- $\alpha$ BGT binding was also highest in the superior colliculus and lowest in the cerebellum, but the other areas of the brain differed in their rank order binding of $\alpha \mathrm{BGT}$ compared to nicotine.

\section{Discussion}

There is now much biochemical evidence to show that the neuronal component bound by the anti-electric organ AChR antibody $\mathrm{mAb} 35$ is a neuronal $\mathrm{AChR}$. The component from chicken brain binds some antibodies to electric organ and skeletal muscle AChR and does not bind $\alpha$ BGT, but it can be affinity-labeled with ${ }^{3} \mathrm{H}-\mathrm{BAC}$ (Whiting and Lindstrom, 1986). Similarly, the $\mathrm{mAb} 35$ binding component from chicken ciliary ganglion cells binds some $\mathrm{mAbs}$ to electric organ and skeletal muscle and does not bind $\alpha \mathrm{BGT}$, but it can be modulated with cholinergic ligands (Smith et al., 1986). In addition, antisera to the chicken brain component specifically block the ACh-induced depolarization 


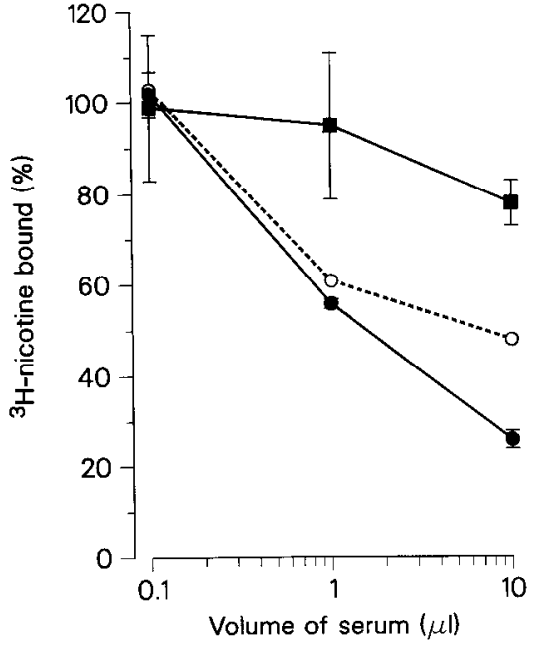

Figure 7. Inhibition of ${ }^{3} \mathrm{H}$-nicotine binding to immobilized chick neuronal AChR by anti-chick neuronal AChR serum. Chick brain detergent extract $(80 \mathrm{ml})$ was recirculated through $250 \mu \mathrm{l}$ of mAb 35-Sepharose for $15 \mathrm{hr}, 4^{\circ} \mathrm{C}$, and then divided into aliquots containing $0.47 \mathrm{pmol}{ }^{125} \mathrm{I}-$ $\mathrm{mAb} 35$ binding sites per aliquot. After washing with $2 \times 1 \mathrm{ml}$ PBS, $0.5 \%$ Triton $X-100$, the aliquots were incubated for $90 \mathrm{~min}$, room temperature, with periodic agitation in $100 \mu \mathrm{l}$ of rat anti-chick neuronal AChR serum [anti-chick neuronal AChR titer of $66 \mu \mathrm{M}$ determined by solid-phase radioimmunoassay (Whiting and Lindstrom, 1986)] or normal rat serum, diluted in the same buffer. ${ }^{3} \mathrm{H}-$ Nicotine $(11 \mu \mathrm{l} 100 \mathrm{~nm})$ was then added (to give a final concentration of $10 \mathrm{nM}$ ) and after 15 min incubation the ${ }^{3} \mathrm{H}$-nicotine bound was determined as described in Materials and Methods. The total binding of ${ }^{3} \mathrm{H}$-nicotine was determined in the absence of any serum, and binding in the presence of serum expressed as a percentage of the total binding. Nonspecific binding, determined in the presence of $1 \mathrm{~mm}$ carbachol, was less than $2 \%$ of the total binding. Each point is the mean \pm SD of triplicate determinations. Symbols: $\mathbf{n}{ }^{3} \mathrm{H}$-nicotine binding in the presence of normal rat serum; , ${ }^{3} \mathrm{H}$-nicotine binding in the presence of anti-chicken neuronal AChR serum; $\mathrm{O}$, specific inhibition $\left({ }^{3} \mathrm{H}\right.$-nicotine binding in the presence of anti-chicken neuronal AChR serum after subtraction of the nonspecific inhibition of binding by normal rat serum).

of cultured chicken ciliary ganglion cells (Stollberg et al., 1986). Here we demonstrate that the chicken brain component binds ${ }^{3} \mathrm{H}$-nicotine with high affinity. Further, we show that this chicken neuronal $\mathrm{AChR}$ and a homologous component from rat brain have a nicotinic cholinergic pharmacology that is essentially identical to that found by other workers who have investigated the binding of ${ }^{3} \mathrm{H}$-nicotine to rodent brain membranes (Abood et al., 1980; Clarke et al., 1984; Marks and Collins, 1982; Romano and Goldstein, 1980; Yamada et al., 1985).

We detected ${ }^{3} \mathrm{H}$-nicotine binding by immobilizing the neuronal AChR upon antibody-affinity supports. This both concentrated and purified the neuronal AChR and allowed assays of solubilized AChR to be performed in microfuge tubes, which was both very rapid and convenient. Additionally, the nonspecific binding of ${ }^{3} \mathrm{H}$-nicotine, which has been a problem when examining binding to membrane preparations, was negligible (Fig. 1, for example). Both chicken and rat neuronal AChRs bound ${ }^{3} \mathrm{H}$-nicotine with high affinity. Other workers have investigated the binding of this ligand to rodent brain membranes and have reported a wide range of binding affinities, to either a single site (Abood et al., 1980; Clarke et al., 1984; Marks and Collins, 1982) or more than one site (Larsson and Nordberg, 1985; Romano and Goldstein, 1980; Yamada et al., 1985). We found no evidence for more than one binding affinity. However, the heterogeneity of nicotine binding to rodent brain membranes observed by some workers suggested that the neuronal AChR characterized in this report may represent only one of several
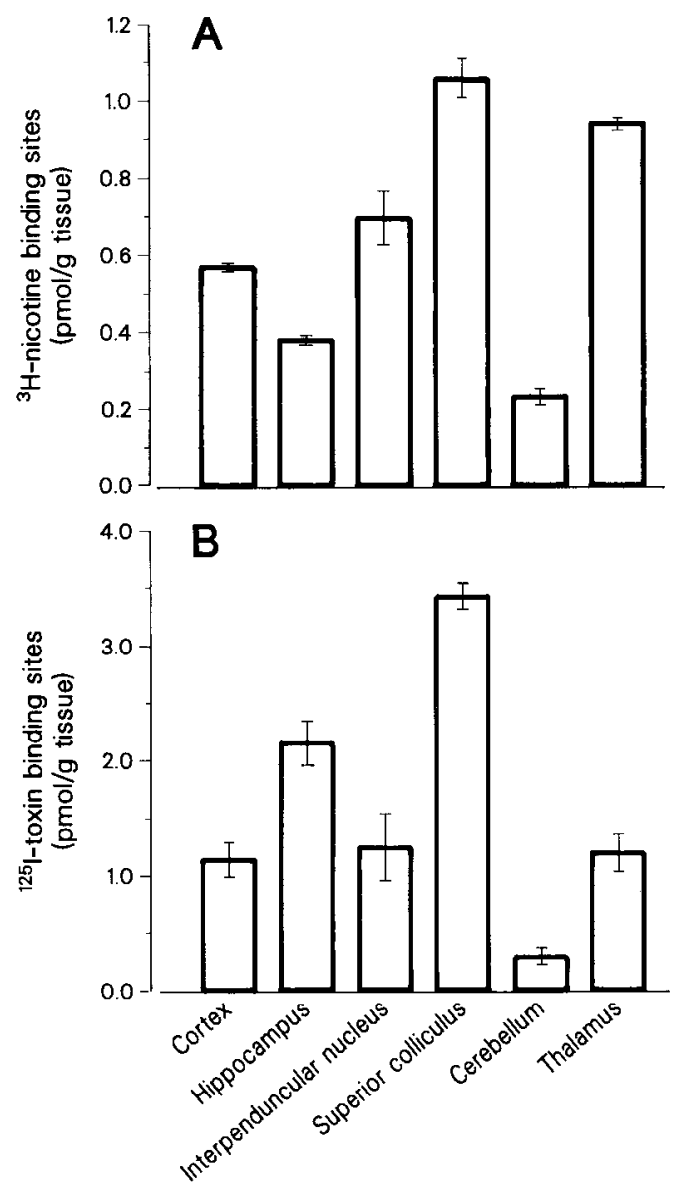

Figure 8. Regional distribution of ${ }^{3} \mathrm{H}$-nicotine binding sites and ${ }^{125} \mathrm{I}-$ $\alpha$ BGT binding sites in rat brain. Detergent extracts of each of the dissected brain regions (pooled from 10-15 rats) were prepared as described in Materials and Methods. $A,{ }^{3} \mathrm{H}-\mathrm{Nicotine}$ binding. Detergent extracts $(180 \mu \mathrm{l})$ were gently shaken for $20 \mathrm{hr}, 4^{\circ} \mathrm{C}$, with $50 \mu \mathrm{l}$ of anti-chick neuronal AChR-Sepharose. The aliquots were washed with $2 \times 1 \mathrm{ml}$ of PBS, $0.5 \%$ Triton X-100 and incubated with $100 \mu \mathrm{l}$ of $20 \mathrm{~nm}{ }^{3} \mathrm{H}$ nicotine for $15 \mathrm{~min}$, room temperature. ${ }^{3} \mathrm{II}-\mathrm{Nicotine}$ bound was determined as described in Materials and Methods and expressed as nicotine binding sites/g brain tissue (wet wt). Nonspecific binding was determined by labeling in the presence of $1 \mathrm{~mm}$ carbachol and subsequently subtracted. Each column is the mean \pm SD of triplicate determinations. $B,{ }^{125} \mathrm{I}-\alpha \mathrm{BGT}$ binding. Toxin binding to each detergent extract was determined by DEAE assay, as described in Materials and Methods and expressed as toxin binding sites/g tissue (wet wt). Nonspecific binding was determined by labeling in the presence of $1 \mu \mathrm{M}$ nonradioactive $\alpha \mathrm{BGT}$ and has been subtracted. Each column is the mean $\pm \mathrm{SD}$ of quadruplicate determinations.

nicotine binding proteins in the CNS. To address this possibility, we investigated whether an immobilized $\mathrm{mAb}$ to the chicken neuronal AChR, mAb 270, could deplete ${ }^{3} \mathrm{H}$-nicotine binding sites from brain detergent extracts. mAb 270 bound virtually all of the ${ }^{3} \mathrm{H}$-nicotine binding components (Fig. 4). Thus, the neuronal AChR characterized here represents the major, and perhaps the only, high-affinity nicotine binding component in chicken and rat brain. We cannot discount the possibility that a small population of high-affinity nicotine binding sites $(<10 \%$ of the total) or a low-affinity nicotine binding component exists that is not bound by anti-neuronal AChR antibodies.

Schneider and coworkers (1985) have recently identified and solubilized a component from chicken brain and optic lobe that binds ${ }^{3} \mathrm{H}-\mathrm{ACh}$ with high affinity but does not bind $\alpha \mathrm{BGT}$. As is discussed further below, it is likely that this component is the same as the neuronal AChR bound by $\mathrm{mAb} 35$. However, these 
authors reported that the ${ }^{3} \mathrm{H}-\mathrm{ACh}$ binding site was present at $>1 \mathrm{pmol} / \mathrm{g}$ brain. We have consistently found that the $\mathrm{mAb} 35$ binding site is present at $0.2-0.4 \mathrm{pmol} / \mathrm{g}$ chicken brain (Lindstrom et al., 1983; Whiting and Lindstrom, 1986) and report here that the ${ }^{3} \mathrm{H}$-nicotine binding sites are present in very similar quantities, as would be expected if they bind to the same molecule in approximately stoichiometric amounts. The reason for this difference is not currently known, but one possibility is that it represents developmental changes in the expression of neuronal AChRs: Schneider and coworkers used 2-d-old chicks, whereas we have used adult chickens.

In rat brain we have found that there are $0.9 \pm 0.03 \mathrm{pmol} / \mathrm{g}$ brain of ${ }^{3} \mathrm{H}$-nicotine binding sites using a gel-filtration assay, and the slightly lower value of $0.7 \pm 0.07 \mathrm{pmol} / \mathrm{g}$ using antichicken neuronal AChR-Sepharose to immobilize the nicotine binding site. This value is lower than the amount of ${ }^{3} \mathrm{H}$-nicotine and ${ }^{3} \mathrm{H}-\mathrm{ACh}$ binding sites in rodent brain determined by other workers, 3-4.5 pmol/g brain (Marks and Collins, 1982; Reulecke and Hucho, 1985; Romano and Goldstein, 1980).

The pharmacology of both the chicken and rat neuronal AChRs was characteristic in having a high affinity for cholinergic agonists and low affinity for cholinergic antagonists (Table 1). As predicted from previous studies (Whiting and Lindstrom, 1986), $\alpha$ BGT showed no inhibition of ${ }^{3} \mathrm{H}$-nicotine binding to immobilized neuronal $\mathrm{AChR}$ at up to micromolar concentrations. In general, the affinities of various cholinergic ligands for the neuronal AChRs are in excellent agreement with the values obtained by other workers for binding to intact brain membranes (Clarke et al., 1984; Marks and Collins, 1982; Romano and Goldstein, 1980; Yamada et al., 1985). The data are also in good agreement with values obtained by Schwartz et al. (1982), who determined the inhibition of ${ }^{3} \mathrm{H}-\mathrm{ACh}$ to rodent brain membranes by cholinergic ligands. In a more recent study, these workers have demonstrated autoradiographically that ${ }^{3} \mathrm{H}-\mathrm{ACh}$ and ${ }^{3} \mathrm{H}-n i c o-$ tine have almost identical binding patterns on rat brain sections (Clarke et al., 1985a). Similarly, the regional distribution of ${ }^{3} \mathrm{H}$ nicotine binding sites in rat brain found in this study was in good agreement with both the distribution of membrane-bound nicotine binding sites determined by other workers (Marks and Collins, 1982; Yamada et al., 1985) and with the distribution of membrane-bound ${ }^{3} \mathrm{H}-\mathrm{ACh}$ binding sitcs (Schwartz ct al., 1982). Furthermore, the agonist binding site of chicken brain and optic lobe, defined by its high affinity for binding ${ }^{3} \mathrm{H}-\mathrm{ACh}$ (Schneider et al., 1985) also has essentially identical pharmacology to the neuronal AChR described here. Thus, it is very likely that the ${ }^{3} \mathrm{H}-\mathrm{ACh}$ binding component, the ${ }^{3} \mathrm{H}$-nicotine binding component, and the neuronal $\mathrm{AChR}$ defined here are the same.

As others have previously noted, there is a puzzling discrepancy between (1) the relatively high affinity of the cholinergic agonists compared to their concentration required for stimulation in the CNS (Brown et al., 1983), and (2) the relatively low affinities of antagonists such as hexamethonium and mecamylamine, which act on the CNS nicotinic AChR at relatively low concentrations (Brown et al., 1983; Clarke et al., 1985b). In Torpedo electric organ, bound agonist induces conversion of AChR from a low- to high-affinity desensitized form (for review, see Anholt et al., 1985; Popot and Changeux, 1984). One may speculate that the neuronal AChR undergoes an analogous conversion. Additionally, one may consider that some antagonists may also block function by binding in the cation channel. Whether these or other possibilities can account for the above disparities requires further elucidation.

Both the chicken and rat neuronal AChRs could be aflinitylabeled with BAC after reduction with DTT, demonstrating the existence of a disulfide bond adjacent to the ACh binding site. This feature is conserved in electric organ and skeletal muscle AChRs (Damle et al., 1978; Wolosin et al., 1980), in the brain $\alpha$ BGT binding protein (Kemp et al., 1985; Norman et al., 1982), as well as in neuronal AChRs. Conservation of this disulfide bond suggests that it has an important structural or functional role in this family of proteins with a shared evolutionary history. We found no evidence that BAC labels the neuronal AChR in a biphasic manner, as is known for electric organ and skeletal muscle AChR due to preferential labeling of 1 of the 2 binding sites (Wolosin et al., 1980). Similarly, the inhibition of ${ }^{3} \mathrm{H}$ nicotine binding to neuronal AChR by curare (Fig. 5) was clearly indicative of binding with a single affinity. In contrast, it is known that curare binds with a higher affinity to 1 of the 2 neurotransmitter binding sites on electric organ and skeletal muscle AChRs (Neubig and Cohen, 1979; Sine and Taylor, 1981; Whiting et al., 1985). Thus, there is either only 1 neurotransmitter binding site per neuronal AChR molecule, or, more likely, there are 2 or more sites that are indistinguishable by their susceptibility to affinity labeling or by their affinity for certain antagonists. It is interesting to note that the $\alpha \mathrm{BGT}$ binding protein from rat brain is also affinity-labeled in a monophasic manner (Kemp et al., 1985), suggesting that this feature has diverged from skeletal muscle AChR but is conserved in the brain $\alpha \mathrm{BGT}$ binding protein and the brain AChR described in this report.

Here we have shown that the chicken neuronal $A C h R$ bound by $\mathrm{mAb} 35$ has a nicotinic cholinergic pharmacology. Using both a cross-reactive antiserum and a mAb, we have further demonstrated a homologous neuronal $\mathrm{AChR}$ exists in rat brain that probably has the same high-affinity agonist binding site as has been identified by previous workers. Since the antisera specifically block ACh-induced depolarization of chicken ciliary ganglion cells (Stollberg et al., 1986), one may speculate that the mammalian neuronal $A C h R$ bound by these antisera is also a functional AChR. Furthermore, mAbs to neuronal AChRs are valuable probes that should allow the purification and characterization of the mammalian neuronal $\mathrm{AChR}$, immunohistochemical mapping of the nicotinic cholinergic pathways in the mammalian brain, and molecular genetic studies of the neuronal $\mathrm{AChR}$.

\section{References}

Abood, L. G., D. T. Reynolds, and J. M. Bidlack (1980) Stcreospecific $\left[{ }^{3} \mathrm{H}\right]$ nicotine binding to intact and solubilized rat brain membranes and evidence for its noncholinergic nature. Life Sci. 27: 1307-1314.

Anholt, R., J. Lindstrom, and M. Montal (1985) In The Molecular Basis of Neurotransmission: Structure and Function of the Nicotinic Acetylcholine Receptor, A. N. Martinose, ed., pp. 335-401, Plenum, New York.

Blatt, Y., M. Montal, J. Lindstrom, and M. Montal (1986) Monoclonal antibodies directed against epitopes in the $\beta$ and $\alpha$ subunits of the Torpedo cholinergic receptor block channel function. J. Neurosci. 6: 481-486.

Brown, D. A., and L. Fumigalli (1977) Dissociation of $\alpha$ bungarotoxin and receptor block in the rat superior cervical ganglion. Brain Res. 129: 165-168.

Brown, D. A., R. J. Docherty, and J. V. Halliwcll (1983) Chemical transmission in the rat interpeduncular nucleus in vitro. J. Physiol. (Lond.) 341: 655-670.

Carbonetto, S. T., D. M. Fambrough, and K. J. Muller (1978) Non equivalence of $\alpha$ bungarotoxin receptors and acetylcholine receptor in chick sympathetic neurons. Proc. Natl. Acad. Sci. USA 75: 10161020 .

Chiou, C. Y., and B. V. R. Sastry (1968) Acetylcholinesterase hydrolysis of halogen substituted acetylcholines. Biochem. Pharmacol. 17: 805-815.

Clarke, P. B. S., C. B. Pert, and A. Pert (1984) Autoradiographic distribution of nicotine receptors in rat brain. Brain Res. 323: 390395.

Clarke, P. B. S., R. D. Schwartz, S. M. Paul, C. B. Pert, and A. Pert (1985a) Nicotine binding in rat brain: Autoradiographic comparison of $\left[{ }^{3} \mathrm{H}\right]$ acetylcholine, $\left[{ }^{3} \mathrm{H}\right]$ nicotine, and $\left[{ }^{125} \mathrm{I}\right] \alpha$ bungarotoxin. J. Neurosci. 5: 1307-1315.

Clarke, P. B. S., D. W. Hommer, A. Pert, and L. R. Skirboll (1985b) 
Electrophysiological actions of nicotine on substantia nigra single units. Br. J. Pharmacol. 85: 827-835.

Conti-Tronconi, B., S. Dunn, E. Barnard, J. Dolly, F. Lai, N. Ray, and M. Raftery (1985) Brain and muscle nicotinic acetylcholine receptors are different but homologous proteins. Proc. Natl. Acad. Sci. USA 82: 5208-5212.

Damle, V. N., M. McLaughlin, and A. Karlin (1978) Bromoacetylcholine as an affinity label of the acetylcholine receptor from Torpedo californica. Biochem. Biophys. Res. Commun. 84: 845-851.

Freeman, J. A., J. T. Schmidt, and R. E. Oswald (1980) Effect of $\alpha$ bungarotoxin on retinotectal synaptic transmission in the goldfish and the toad. Neuroscience 5: 929-942.

Jacob, M., and D. Berg (1983) The ultrastructural localization of alpha bungarotoxin binding sites in relation to synapses on chick ciliary ganglion neurons. J. Neurosci. 3: 260-271.

Jacob, M. H., D. K. Berg, and J. M. Lindstrom (1984) Shared antigenic determinant between Electrophorus acetylcholine receptor and a synaptic component on chick ciliary ganglia neurons. Proc. Natl. Acad. Sci. USA 81: 3223-3227.

Kemp, G., L. Bentley, M. G. McNamee, and B. J. Morley (1985) Purification and characterization of the $\alpha$ bungarotoxin binding protein from rat brain. Brain Res. 347: 274-283.

Kouvelas, E. D., M. A. Dichter, and L. A. Greene (1978) Sympathetic neurons develop receptors for $\alpha$ bungarotoxin in vitro, but toxin does not block nicotinic receptors. Brain Res. 154: 83-93.

Larsson, C., and A. Nordberg (1985) Comparative analysis of nicotine like receptor-ligand interactions in rodent brain homogenate. J. Neurochem. 45: 24-31.

Lindstrom, J. M., B. Einarson, and S. Tzartos (1981a) Production and assay of antibodies to acetylcholine receptors. In Methods in Enzymology, Vol. 74: Immunochemical Techniques, H. Van Vunakis and J. Langone, eds., pp. 432-460, Academic Press, New York.

Lindstrom, J., S. Tzartos, and B. Gullick (1981b) Structure and function of acetylcholine receptors studied using monoclonal antibodies. Ann. NY Acad. Sci. 377: 1-19.

Lindstrom, J., S. Tzartos, W. Gullick, S. Hochschwender, L. Swanson, M. Montal, M. Jacobs, and P. Sargent (1983) Use of monoclonal antibodies to study acetylcholine receptors from electric organs, muscle, and brain and the autoimmune response to receptor in myasthenia gravis. Cold Spring Harbor Symp. Ouant. Biol. 48: 89-99.

Marks, M. J., and A. C. Collins (1982) Characterization of nicotine binding in mouse brain and comparison with binding of $\alpha$ bungarotoxin and quinuclidinyl benzilate. Mol. Pharmacol. 22: 554-564.

Marshall, L. M. (1981) Synaptic localization of $\alpha$ bungarotoxin binding which blocks nicotinic transmission at frog sympathetic neurons. Proc. Natl. Acad. Sci. USA 78: 1948-1952.

Neubig, R. R., and J. B. Cohen (1979) Equilibrium binding of $\left[{ }^{3} \mathrm{H}\right]$ tubocurarine and $\left[{ }^{3} \mathrm{H}\right]$ acetylcholine by Torpedo post-synaptic membranes: Stoichiometry and ligand interactions. Biochemistry 18: 54645476.

Norman, R. I., F. Mehraban, E. A. Barnard, and J. O. Dolly (1982) Nicotinic acetylcholine receptor from chick optic lobe. Proc. Natl. Acad. Sci. USA 79: 1321-1325.

Patrick, J., and W. B. Stallcup (1977a) $\alpha$ Bungarotoxin binding and cholinergic receptor function on a rat sympathetic nerve line. J. Biol. Chem. 252: 8629-8633.

Patrick, J., and W. B. Stallcup (1977b) Immunological distinction between acetylcholine receptor and the $\alpha$ bungarotoxin binding component on sympathetic neurons. Proc. Natl. Acad. Sci. USA 74:46894692.
Popot, J.-L., and J.-P. Changeux (1984) Nicotinic receptor of acetylcholine: Structure of an oligomeric integral membrane protein. Physiol. Rev. 64: 1162-1239.

Ravdin, P. M., and D. K. Berg (1979) Inhibition of neuronal acetylcholine sensitivity by $\alpha$ toxins from Bungarus multicinctus venom. Proc. Natl. Acad. Sci. USA 76: 2072-2076.

Reulecke, M., and F. Hucho (1985) High and low affinity binding of $\left[{ }^{3} \mathrm{H}\right]$ acetylcholine at nicotinic cholinergic receptors in rat brain. Neurosci. Lett. 59: 271-276.

Romano, C., and A. Goldstein (1980) Stereospecific nicotinic receptors on rat brain membranes. Science $210: 647-649$.

Schneider, M., C. Adee, H. Betz, and J. Schmidt (1985) Biochemical characterization of two nicotinic receptors from the optic lobe of the chick. J. Biol. Chem. 260: 14505-14512.

Schwartz, R. D., R. McGee, and K. J. Kellar (1982) Nicotinic cholinergic receptors labeled by $\left[{ }^{3} \mathrm{H}\right]$-acetylcholine in rat brain. Mol. Pharmacol. 22: 55-62.

Sine, S. M., and P. Taylor (1981) Relationship between reversible antagonist occupancy and the functional capacity of the acetylcholine receptor. J. Biol. Chem. 256: 6690-6699.

Smith, M. A., J. Stollberg, D. K. Berg, and J. Lindstrom (1985) Characterization of component in chick ciliary ganglia that cross-reacts with monoclonal antibodies to muscle and electric organ acetylcholine receptor. J. Neurosci. 5: 2726-2731.

Smith, M. A. J. F. Margiotta, A. Franco, Jr., J. M. Lindstrom, and D. K. Berg (1986) Cholinergic modulation of an acetylcholine receptorlike antigen on the surface of chick ciliary ganglion neurons in cell culture. J. Neurosci. 6: 946-953.

Stollberg, J., D. K. Berg, K. Wan, and J. M. Lindstrom (1984) Bromoacetylcholine is an affinity ligand for the acetylcholine receptor of chick ciliary ganglion neurons. Soc. Neurosci. Abstr. 2123.

Stollberg, J., P. Whiting, J. Lindstrom, and D. Bcrg (1986) Functional blockade of neuronal acetylcholine receptors by antisera to a putative receptor from brain. Brain Res. 378: 179-182.

Swanson, L. W., J. Lindstrom, S. Tzartos, L. C. Schmued, D. D. M. O'Leary, and W. M. Cowan (1983) Immunohistochemical localization of monoclonal antibodies to the nicotinic acetylcholine receptor in chick midbrain. Proc. Natl. Acad. Sci. USA 80: 4532-4536.

Tzartos, S., and J. M. Lindstrom (1980) Monoclonal antibodies used to probe acetylcholine receptor structure: Localization of the main immunogenic region and detection of similarities between subunits. Proc. Natl. Acad. Sci. USA 77: 755-759.

Tzartos, S. J., D. E. Rand, B. E. Einarson, and J. M. Lindstrom (1981) Mapping of the surface structures of Electrophorus acetylcholine receptor using monoclonal antibodies. J. Biol. Chem. 256: 8635-8645.

Whiting, P. J., and J. M. Lindstrom (1986) Purification and characterization of a nicotinic acetylcholine receptor from chick brain. Biochemistry 25: 2082-2093.

Whiting, P. J., A. Vincent, and J. Newsom-Davis (1985) Monoclonal antibodies to Torpedo acetylcholine receptor: Characterization of antigenic determinants within the cholinergic binding site. Eur. J. Biochem. 150: 533-539.

Wolosin, J. M., A. Lyddiatt, J. O. Dolly, and E. A. Barnard (1980) Stoichiometry of the ligand binding sites in the acetylcholine receptor oligomer from muscle and from electric organ. Eur. J. Biochem. 109: $495-505$

Yamada, S., S. M. Isogai, Y. Kagawa, N. Takayanagi, E. Hayashi, K. Tsuji, and T. Kosuge (1985) Brain nicotinic acetylcholine receptors: Biochemical characterization by neosurugatoxin. Mol. Pharmacol. 28: $120-127$. 